\title{
Could Lehman Brothers' Collapse Be Anticipated? An Examination Using CAMELS Rating System
}

\author{
Apostolos G. Christopoulos \\ University of Athens, Department of Economics, 5 Stadiou str., 10562, Athens, Greece \\ E-mail: axristop@econ.uoa.gr \\ John Mylonakis (Corresponding Author) \\ 10, Nikiforou str., Glyfada, 166 75, Athens, Greece \\ E-mail: imylonakis@vodafone.net.gr \\ Pavlos Diktapanidis \\ Open University of Cyprus, Fotolivos, Drama \\ E-mail:p_diktapan@yahoo.gr
}

Received: February 20, 2011 Accepted: March 3, 2011 doi:10.5539/ibr.v4n2p11

\begin{abstract}
The collapse of Lehman Brothers, the largest investment bank that has ever declared bankrupt has had a major impact among economies and in most stock markets across the globe. For this reason, the case of Lehman Brothers is being examined by analysing its financial particulars of the last five years (2003-2007) using the CAMELS ratios. Research results showed that its credits were found as bad and doubtful while its management appeared to be unwilling and unable to reverse its declining course. Also, the management was not complying with the rules set by the supervisory authorities while the risk management methods followed is regarded as insufficient proportionally to its size. Finally, the bank appeared to be vulnerable against risks or unstable conditions while the supervisory authorities and the US Federal Reserve should have foreseen that Lehman Brothers presented several signs of decline and react accordingly.
\end{abstract}

Keywords: CAMELS rating, Financial Institutions Rating Systems, World Economic Crisis, Banks' Supervising Authorities, Credit Rating Authorities

\section{Introduction}

The current financial crisis that commenced in 2007 has brought forward many weaknesses existing within the globalised financial system, triggering concerns relating to the safety of financial institutions, even states, against potential non-anticipated risks associated with periods of uncertainty (International Monetary Fund, 2009). The presence of defects in supervisory control also emerged, namely the weakness or incompetence of supervisory authorities to prevent similar large-scale crises from taking place, as well as, the "strange" role played by credit rating agencies in the creation of bubbles (Demyank \& Ifterkhar, 2009, The Turner Review, 2009).

A series of events that, three years ago would seem unlikely, have led to extreme drops in global growth rates and have sky rocked unemployment rates, along with a sense of insecurity in almost every country in the world. While the crisis was still unfolding, its strength and extent increased continuously, forcing governments, central banks, analysers, investors, businessmen and consumers to constantly review their concepts and expectations. All former anticipations for reaching an era of financial stability, continuous prosperity and market self-regulation collapsed before the rapid economic aggravation (Freund, 2009).

The collapse of Lehman Brothers, the largest investment bank that has ever declared bankrupt, has had a major impact among economies and in most stock markets across the globe (Baldwin, 2009). For this reason, the case of Lehman Brothers is being examined by analysing its financial particulars of the last five years using the CAMELS ratios. The scope of this paper is to examine whether the bank's collapse was only due to the current crisis or whether it was the result of its malfunctioning, in which case it could have been foreseen and overcome by supervisory authorities and by the Fed. 


\section{The development of CAMELS Rating System}

In 1979, the Uniform Financial Institutions Rating System (UFIRS) was implemented in US banking institutions, and later globally, following a recommendation by the US Federal Reserve (Epstein \& Martin, 2003, Bauer et al, 1998). This system became internationally known with the abbreviation CAMEL, reflecting five assessment areas: capital, asset quality, management, earnings and liquidity ratios (Cox \& Cox, 2006). The CAMELS system focuses on the assessment of the banking system by examining its balance sheet, as well as, profit and loss statement, thus observing the institution's dynamic aspect (Deyoung et all, 2001).

In the new globalised financial system, as with all new financial markets and products, the banks' economic situation can rapidly change than in the past. As a result of the new situation, supervisory authorities were led towards changing their way of approach and assessment, paying more emphasis on ways to overcome and manage risks (Doumpos \& Zopounidis, 2009). As a result of this new situation that was created through the development of the financial system, a further area of assessment was added, that of the initial S, indicating market risk. This took place in 1995 by the US Federal Reserve (Fed) and the Comptroller of the Currency (Hafer, 2005), who replaced CAMEL with CAMELS and added a management assessment system scale from 1 (optimum) to 5 (worse) for risk management (Broz, 1997).

The ratios used to produce the results (Gaillard, 2009) and to evaluate the situation (Jeffrey \& Thomas, 2002) of the financial institution under examination are:

\section{A. Capital Adequacy Ratio}

A bank's capital ratio is a very important index. It can act as a saver for potential risks, as well as, for important decisions that banking institutions take with regard to growth (Shelagh, 2005) and their future course in general. This index is a product of Basil (Kose et all, 2000, BCBS, 2000, 2004, 2005a, 2005b). In order for a banking institution to have capital adequacy, this ratio should be higher than $8 \%$, namely the total amount of capital must be over $8 \%$ of its risk-weighted assets.

\section{CAR= (TIER I + TIER II) / RISK-WEIGHTED ASSETS}

TIER I: forms the basic and own capital and includes: common and preferred stocks, the bank's minority rights in subsidiary companies, convertible bonds.

TIER II: forms the bank's supplementary capital. This is, also, known as hybrid because it includes amounts of capital deriving from bonds issued by the bank itself; these amounts are long-term and offer reduced guarantees to buyers. TIER I is required to be $50 \%$ of the total amount of the numerator. The higher the value of the index, the better the bank's capital adequacy, and the institution can rely on self-financing and have better profitability than other institutions with lower CAR ratios.

\section{B. Asset Quality Ratio}

The asset quality assessment is based on evaluating credit risks associated with a bank's portfolios. A bank's ability to detect, measure, monitor and regulate credit risks is also assessed, while taking into account any provisions against bad and doubtful claims.

\section{(TOTAL NON-PERFORMING LOANS>90 DAYS - PROVISIONS) / TOTAL LOANS}

The nominator contains the net non-performing loans. The total of non-performing loans over 90 days has been defined by Basil II as a critical point for loan repayment. The provisions include reserve capital withheld by the bank in order to compensate for losses originating from loans the delay of which has been provisioned. The lower the index the more accurate the bank provisions of these delays and consequently, the higher the quality and reliability of its portfolios.

\section{Management Quality Ratio}

Management forms the mechanism that makes decisions to ensure the bank's smooth course of operation handles risks and exercises control. Thus, proper management in line with regulations in force is essential for the bank's smooth course of operation.

\section{MANAGEMENT EXPENSES/ SALES}

This ratio measures the percentage of operating expenses in relation to sales. Management expenses include all the operating expenses borne by the bank, while sales include all interest expenses and similar charges from the bank's profit and loss account. The lower the ratio, the better for the bank because it indicates that it has good management. 


\section{Earnings Ratios}

Earnings and profitability form the primary source for capital base increases and are examined in relation to interest rate policies and provisions adequacy. These ratios, also, help support a bank's current and future activities. Strong profits combined with its earnings profile reflect a bank's ability to support current and future tasks. More specifically, this ratio reflects the bank's ability to absorb losses, expand its financing, as well as, its ability to pay dividends to its shareholders, and helps develop an adequate amount of own capital. The assessment of earnings is not only performed in terms of amount and profit tendencies, but also in respect of quality and duration.

\section{(a) ROA= NET PROFITS/ TOTAL ASSETS}

This ratio correlates net profits with total assets and indicates whether asset management is efficient enough to produce profits. The higher the ratio the more efficient the bank; a satisfactory performance would produce a value between $1 \%$ and $2.5 \%$.

\section{(b) ROE= NET PROFITS/ OWN CAPITAL}

This ratio correlates net profits with own capital. The higher the ratio the more the bank uses its own capital in an efficient manner. The more efficient a bank is the easier it is to produce money using its own capital.

\section{E. Liquidity Ratios}

During liquidity assessment, the current liquidity status of the bank is taken into account in relation to the liabilities it has undertaken. It also tests the bank's ability to deal with changes in its financing resources, as well as, changes in market conditions which alter the fast liquidation of its assets, with the least possible losses.

\section{(a) LOANS TO TOTAL DEPOSITS (L1) = TOTAL LOANS / TOTAL DEPOSITS}

This ratio presents the extent in which deposits are maintained for issuing loans and therefore the bank's dependence in interbank markets. The lower this ratio is the better the bank's liquidity status, while a value of less than one offers security for loans since deposits alone are sufficient to cover such loans.

\section{(b) CIRCULATING ASSETS TO TOTAL ASSETS (L2) = CIRCULATING ASSETS/ TOTAL ASSETS}

This ratio gives us a bank's liquidity status of circulating assets, such as cash in hand, claims against other banking institutions and its trading, investment and derivatives portfolios. The ratio offers banks the ability to know the extent if their liabilities that may be covered by its not directly available assets. The higher the bank's ratio, the better its liquidity status.

\section{F. Sensitivity to market Ratio}

A bank's assessment on sensitivity towards market risks examines the extent to which potential changes in interest rates, foreign currency exchange rates, product purchase and selling prices, affect the bank's profits and the value of its assets.

\section{TOTAL SECURITIES TO TOTAL ASSETS = TOTAL SECURITIES / TOTAL ASSETS}

Market forces, especially in the recent years, consist of a major reason for changes in the viability of banks. Price movements in favour of a bank's portfolio may boost the Bank's results whereas unfavorable movements may create severe problems to the Bank. This ratio correlates a bank's total securities portfolio with its assets and gives us the percentage change of its portfolio in changes of interest rates or other issues related to the issuers of the securities. The lower the value of this ratio, the better for the bank since this indicates that its reactions towards market risks are appropriate. On the other hand, a higher value of this ratio would indicate that the bank's portfolio is susceptible to market risks.

\section{Research Results}

\section{A. CAPITAl RATIO}

$2003 \mathrm{CAR}=(13,174$ TIER $\mathrm{I}+2,226$ TIER II $) / 156,031 \mathrm{WEIGHTED}=9.870 \%$
$2004 \mathrm{CAR}=(14,921$ TIER $\mathrm{I}+2,925$ TIER II $) / 185,727 \mathrm{WEIGHTED}=9.609 \%$
$2005 \mathrm{CAR}=(16,794$ TIER $\mathrm{I}+3,407$ TIER II $) / 221,434 \mathrm{WEIGHTED}=9.123 \%$
$2006 \mathrm{CAR}=(19,191$ TIER $\mathrm{I}+5,881$ TIER II $) / 287,021 \mathrm{WEIGHTED}=8.735 \%$
$2007 \mathrm{CAR}=(22,491$ TIER $\mathrm{I}+7,645$ TIER II $) / 414,638 \mathrm{WEIGHTED}=7.268 \%$

Results in Table 1 show that Lehman Brothers maintained a very low capital ratio while in 2007 this fell below the limit of $8 \%$. The ratio decline was continuous over the years. This means that the financial situation of Lehman 
Brothers was not good and continued to get worse each year. Its bad and doubtful claims were very high while its access to capital markets was difficult.

Its inadequate capitals made Lehman Brothers unprotected against regular and extraordinary risks, making its support by shareholders or other sources a matter of urgency. Supervisory authorities should have exercised immediate pressure and should have imposed strict measures from the time its capital inadequacy had reached the levels considered as unsafe for the Group's survival.

\section{B. ASSETS RATIO}

2003 (852 NON-PERFORMING - 459 PROVISIONS) / 15,310 LOANS $=0.02567$

2004 (1,188 NON-PERFORMING - 563 PROVISIONS) / 18,763 LOANS $=0.033316$

2005 (1,255 NON-PERFORMING - 649 PROVISIONS) / 21,643 LOANS $=0.027986$

2006 (2,054 NON-PERFORMING - 1,119 PROVISIONS) / 27,971 LOANS $=0.033433$

2007 (4,073 NON-PERFORMING - 1,731 PROVISIONS) / 43,277 LOANS $=0.054115$

As mentioned during this analysis of the asset quality ratio, the lower its value the better for the organisation being examined. In the case of Lehman Brothers, this ratio tended to increase with the exception of 2006 when it was characterised only by minor increase. Indicatively, its value in 2003 was $2.5 \%$ which was more than doubled in 2007 reaching 5.4\% (Table 2). The results that emerge from the asset quality analysis of Lehman Brothers demonstrate its low ability to detect, measure, monitor and regulate credit risks while at the same time considering its bad and doubtful claims; such ability continued to decline each year. The policy adopted by Lehman Brothers in issuing loans was proven to be the worst. By granting loans to insolvent, high-risk borrowers, it led to an increase of its non-performing loans each year, namely its bad and doubtful loans. This fact, combined with the results from its capital ratios, was detrimental to its survival and has finally led to its collapse. Supervisory authorities, along with the US Federal Reserve, should have foreseen the critical situation it was in from the results of its asset quality ratios and make strict recommendations towards immediate improvements, by restraining its credit policies and thoroughly assessing potential borrowers, in order to improve Lehman Brother's internal control.

\section{MANAGEMENT RATIO}

$20034,750 / 17,287=0.274773$

$20046,386 / 21,250=0.300518$

$20057,929 / 32,420=0.244571$

$20069,536 / 46,709=0.204158$

$200710,599 / 59,003=0.179635$

The management of banking institutions, just like the management of enterprises, determines its operation through decisions, ensures the bank's smooth business, handles risks and exercises control. As shown by the Lehman Brothers' management ratios (Table 3), its management has shown signs of improvement and the ratio remains in relatively high levels. This indicates either that its operating expenses have improved in combination with its sales or that its sales have increased. As has emerged by these numbers, the decline of this specific ratio was due to sales, namely the issuing of more loans. By combining results with the above-mentioned ratios it emerges that many of these loans were bad, approved as a result of poor borrower assessment, a task that falls within the responsibilities of the management of Lehman Brothers. The bank's management should have been more flexible and cooperative with respect to recommendations received by supervisory authorities; the latter should have taken further control of the situation and of the policies followed by the bank.

\section{EARNINGS RATIOS}

\section{3}

ROA $=1,699$ NET PROFITS $/ 312,061$ TOTAL ASSETS $=0.005444$

ROE $=1,699$ NET PROFITS $/ 13,174$ OWN ASSETS $=0.128966$

2004

ROA $=2,369$ NET PROFITS $/ 357,168$ TOTAL ASSETS $=0.006633$

$\mathrm{ROE}=2,369$ NET PROFITS $/ 14,920$ OWN ASSETS $=0.15878$

2005

ROA $=3,260$ NET PROFITS $/ 410,063$ TOTAL ASSETS $=0.00795$ 
ROE $=3,260$ NET PROFITS $/ 16,794$ OWN ASSETS $=0.194117$

2006

ROA $=4,007$ NET PROFITS $/$ 503,545 TOTAL ASSETS $=0.007958$

ROE $=4,007$ NET PROFITS / 19,191 OWN ASSETS $=0.208796$

2007

ROA $=4,192$ NET PROFITS $/$ 691,063 TOTAL ASSETS $=0.006066$

ROE $=4,192$ NET PROFITS $/ 22,490$ OWN ASSETS $=0.186394$

An assessment of Lehman Brothers' earnings reveals that its profits are low and insufficient (Table 4). It is obvious that the bank lacks in several areas to such an extent that it is led towards its collapse. As mentioned earlier in the presentation of ratios, a fair price for ROA would be between $1 \%$ and $2.5 \%$. This specific ratio is found well below these limits and, despite the fact that it was moderately increasing until 2006, it remained at low levels while further decreasing in 2007.

The results of Lehman Brothers' earnings ratios show that ROE is close to the average of the acceptable range. Its profits seem to be continuously increasing over the last five years, except 2007, giving the signal of the coming unexpected dramatic collapse. The institution's provisions were proven to be lower than those that should be. Since earnings ratios show a company's ability to support its operations and future activities, the evaluation results of the last five years should have ringed a bell that the bank would face survival issues in periods of potential instability or unexpected risks should it not improve its profits and quality of profits.

\section{E. LIQUIDITY RATIOS}

L1

$200315,310 / 39,999=0.38276$

$200418,763 / 50,140=0.374212$

$200521,643 / 44,975=0.481223$

$200627,971 / 58,609=0.477248$

$200743,277 / 86,346=0.501204$
L2

$2003131,099 / 312,061=0.420106966$

$2004150,077 / 357,168=0.420186019$

$2005179,362 / 410,063=0.437401082$

$2006230,175 / 503,545=0.457109097$

$2007313,103 / 691,063=0.4530744669$

With respect to Lehman Brothers' liquidity ratios, the results relating to this aspect of assessment (Table 5) have shown that Lehman Brothers' L1 ratio results were satisfactory. This means that its loans were less than its deposits. This could indicate that the bank issued part of its loans using the funds available from its deposits and was in position to withhold part of these funds as reserve. The highest value was in 2007 , when the bank issued $50 \%$ of its deposits.

To the contrary, the L2 ratio results show that the directly available assets of Lehman Brothers' circulating assets were low. Therefore, in the event of an emergency, the bank would not be able to directly liquidate $60 \%$ of its total cash reserves, claims against other banking institutions and transaction portfolios, as well as, its investments in derivatives.

It is apparent that the bank's liquidity status, as compared with its liabilities was poor while its management had no contingency plan that could produce the required flexibility when needed. Moreover, supervisory authorities should have foreseen the risks entailed in Lehman Brothers' liquidity problems and should have imposed regulations and measures to improve its status and prevent its collapse.

\section{F. SENSITIVITY RATIO}

$2003142,218 / 312,061=0.45573782$

$2004174,598 / 357,168=0.488839986$

$2005140,743 / 410,063=0.343222870$

$2006225,196 / 503,545=0.44722120$

$2007301,234 / 691,063=0.43589947$

The data available shows that Lehman Brothers suffered from poor management of risk sensitivity (Table 6). The ratio presented several fluctuations throughout the examined period of five years, reaching its peak of almost $50 \%$ in 2004. This shows that the bank was neither prepared nor protected to face unexpected risks in periods of instability. As a pure Investment Financial Institution, Lehman Brothers is exposed to even higher interest rate variations, 
foreign exchange rates, product purchase and sales prices affecting its profits, as well as, to the value of its assets. Especially, following the globalisation of the financial system, with the extremely rapid developments in data circulation and the changes it entails, Lehman Brothers, being an investment bank, should have ensured its protection against market risks. On the other hand, supervisory authorities had the obligation to diagnose the problem at hand and impose strict measures to protect and secure Lehman Brothers' profits and assets.

\section{Lehman Brothers' Combined Rating Scores}

The combined rating scores of banks using the CAMELS rating system are usually conducted to compare results among different banking institutions. This enables us to draw conclusions on which banking institutions are in better condition and which suffer. Given that this paper analysis concerns only Lehman Brothers, and therefore it does not intents to rate the total number of banks within a sector, this paper aims at comparing the results of this particular bank across several years, in order to see whether CAMELS may consist of a reliable method to foreseen future problems of banks. This method works as follows:

All individual sector ratios analysed above are scaled from 1 to 5, with five indicating the highest performance and one the lowest. Then, an importance coefficient is (subjectively) selected, again in a scale of 1-5, for each CAMELS assessment area. The results prove that the coefficient of each assessment area for a specific year is multiplied by the score of the respective ratio representing that particular area (for example, the capital adequacy coefficient is multiplied by the score of the CAR ratio for that year) while the remaining areas are then added in the same way as the first. The higher the result the better the status of the bank (or banks) being examined. In this case, the coefficients selected for the individual areas are: $C=3.5 \mathrm{~A}=1.5 \mathrm{M}=1 \mathrm{E}=3 \mathrm{~L}=2 \mathrm{~S}=2$. The results and data of the assessment are shown in Tables $7 \& 8$.

From the combined rating assessment of Lehman Brothers using the CAMELS method it emerges that the best years in terms of combined assessment is 2005 and 2006 while the bank's situation became notably worse the following year, which was also the worst year out of the five-year examined period. This is expressed as follows: in 2007, compared with the previous years, Lehman Brothers was found at the worst possible situation. Its credits are considered as bad and doubtful while its management appears to be unwilling and unable to reverse its declining course. The management is not complying with the rules set by the supervisory authorities while the risk management methods followed is regarded as insufficient, proportionally to its size. The bank appears to be vulnerable against risks or unstable conditions. Based on Camels' ratings examination, the supervisory authorities and the US Federal Reserve should have foreseen that Lehman Brothers presented several signs of decline, which were evident from the analysis of its data and should have taken strict steps and measures in order to prevent the possibility of and its actual collapse.

\section{Conclusions}

The current economic crisis has greatly stirred the foundations of the financial system and its future across the globe. The financial map is now irreversibly marked with the collapse of large financial colossi, such as Lehman Brothers which was the object of research in the present study. Yet, the CAMELS rating analysis showed that the Group's collapse was not, only, due to the outbreak and extent of the crisis. The role played by credit rating agencies is extensive considering that Lehman Brothers was in fact an investment bank (the fourth largest) that collapsed while having received excellent ratings. For reasons of speculative gains, the precise Group was presented as a healthy organisation, concealing its problematic status while its portfolio consisted of a pile of bad and doubtful structured bonds.

The US Federal Reserve was, also, greatly responsible, as following the results of the above CAMELS analysis, it should have foreseen the upcoming collapse and impose strict measures to Lehman Brothers, accompanied by strict monitoring to ensure compliance (Greenspan, 2008). To the contrary, the Fed did not proceed with such actions and further refused to finance Lehman Brothers in times of difficulty, as it had done in the case of Bears Stern a couple of months earlier, when it had guaranteed its sale and had later proceeded with state ownership of Fannie Mae and Freddie Mac, with loans amounting to 12 trillion dollars in their portfolio. Unfortunately, it had not predicted the chain of events that would follow the collapse of Lehman Brothers nor its size and intensity.

The poor ratings scored by Lehman Brothers over the last five years before its collapse, should force supervisory authorities to review their way of operation, becoming more effective and diagnostic in predicting and interpreting possible market upheavals, in order to avoid any similar events (Altman \& Rijken, 2004). Currently, Basel III guidelines are supposed to treat these discrepancies, giving more emphasis on the enhancements of equity (TIER I). Finally, credit rating agencies should, also, review their way of operation in such a way as to ensure transparency of assessments and maintain their international market worthiness. 


\section{References}

Altman, E. I. \& Rijken, H.A. (2004). How rating agencies achieve rating stability. Journal of Banking and Finance, Vol. 28, 2679-2714.

Baldwin, R. (2009). The great trade collapse: What caused it and what does it mean?. Introduction in The great trade collapse: causes, consequences and prospects, CEPR, November.

Basel Committee on Banking Supervision BCBS, (2000). Range of Practice in Banks' Internal Ratings Systems. Discussion Paper, Bank for International Settlements, Basel, January.

Basel Committee on Banking Supervision BCBS. (2004). International Convergence of Capital Measurements and Capital Standards - A Revised Framework. Bank for International Settlements, Basel, June.

Basel Committee on Banking Supervision BCBS. (2005a). Studies on the Validation of Internal Rating Systems. Working Paper No. 14, Bank for International Settlements, Basel, February.

Basel Committee on Banking Supervision BCBS. (2005b). Validation of low-default portfolios in the Basel II Framework. Newsletter No. 6, Bank for International Settlements, Basel, September.

Bauer, P.W., Berger, A.N., Ferrier, G.D. \& Humphrey, D.B. (1998). Consistency conditions for regulatory analysis of financial institutions: A comparison of frontier efficiency methods, Journal of Economics and Business, Vol. 50, 85-114.

Broz, L. (1997). The International Origins of the Federal Reserve System. Cornell University Press.

Clark, J.A. \& Thomas F. (2002). X-Efficiency in Banking: Looking beyond the Balance. Journal of Money, Credit and Banking, Vol. 34, No. 4, 987-1013

Cox, D. \& Cox, M. (2006). The Mathematics of Banking and Finance. John Wiley \& Sons Ltd.

Demyanyk, Y. \& Iftekhar, H. (2009). Financial Crises and Bank Failures: A Review of Prediction Methods. FED Of Cleveland, Working Paper 09 04R.

Deyoung, R., Flannery, M.J., Lang, W.W. \& Sorescu, S.M. (2001). The Information Content of Bank Exam Ratings and Subordinated Debt Prices. Journal of Money, Credit and Banking, Vol. 33, No. 4, 900-925.

Doumpos, M. \& Zopounidis, C. (2009). A Multicriteria Bank Rating System. European Working Group "Multiple Criteria Decision Aiding”, Spring, Series 3, No 19, 17-19.

Epstein, L. \& Preston, M. (2003). The Complete Idiot's Guide to the Federal Reserve. Alpha Books.

Freund, C. (2009). The trade response to globaldownturns. Section II, Article 7, in "The great trade collapse: causes, consequences and prospects", CEPR, November.

Gaillard, N. (2009). The Determinants of Moody's Sub-Sovereign Ratings", International Research Journal of Finance and Economics, Issue 31, 194-209.

Greenspan, A. (2008). We will never have a perfect model of risk. Financial Times, March 16, 2008.

Hafer, R. W. (2005). The Federal Reserve System: An Encyclopedia, Greenwood Press, Vol. 451: 280.

Heffernan, S. (2005). Modern Banking, Cass Business School. City University, London.

International Monetary Fund (2009). Global Financial Stability Report. Chapter 1, October, 5.

Kose, J., Saunders, A. \& Senbet, L.W. (2002). A Theory of Bank Regulation and Management Compensation. The Review of Financial Studies, Vol. 13, No. 1, 95-125.

The Turner Review (2009). A regulatory response to the global banking crisis. Financial Services Authority, March, $1-117$. 
Table 1. CAR

\begin{tabular}{|c|c|}
\hline YEAR & CAR \\
\hline 2003 & $9,870 \%$ \\
\hline 2004 & $9.609 \%$ \\
\hline 2005 & $9.123 \%$ \\
\hline 2006 & $8.735 \%$ \\
\hline 2007 & $7.268 \%$ \\
\hline
\end{tabular}

Table 2. Assets Ratios

\begin{tabular}{|c|c|}
\hline YEAR & ASSETS RATIO \\
\hline 2003 & 0.02567 \\
\hline 2004 & 0.03331 \\
\hline 2005 & 0.02800 \\
\hline 2006 & 0.03343 \\
\hline 2007 & 0.05412 \\
\hline
\end{tabular}

Table 3. Management ratios

\begin{tabular}{|c|c|}
\hline YEAR & MANAGEMENT RATIO \\
\hline 2003 & 0.274773 \\
\hline 2004 & 0.300518 \\
\hline 2005 & 0.244571 \\
\hline 2006 & 0.204158 \\
\hline 2007 & 0.179635 \\
\hline
\end{tabular}

Table 4. Earnings Ratios

\begin{tabular}{|c|c|c|}
\hline YEAR & ROA & ROE \\
\hline 2003 & 0.005444 & 0.128966 \\
\hline 2004 & 0.006633 & 0.15878 \\
\hline 2005 & 0.007950 & 0.194117 \\
\hline 2006 & 0.007958 & 0.208796 \\
\hline 2007 & 0.006066 & 0.186394 \\
\hline
\end{tabular}

Table 5. Liquidity Ratios

\begin{tabular}{|c|c|c|}
\hline YEAR & L1 & L2 \\
\hline 2003 & 0.382760 & 0.420106966 \\
\hline 2004 & 0.374212 & 0.420186019 \\
\hline 2005 & 0.481223 & 0.437401082 \\
\hline 2006 & 0.477248 & 0.457109097 \\
\hline 2007 & 0.501204 & 0.453074466 \\
\hline
\end{tabular}

Table 6. Sensitivity Ratios

\begin{tabular}{|c|c|}
\hline YEAR & SENSITIVITY \\
\hline 2003 & 0.455738 \\
\hline 2004 & 0.488840 \\
\hline 2005 & 0.343223 \\
\hline 2006 & 0.447221 \\
\hline 2007 & 0.435899 \\
\hline
\end{tabular}


Table 7. Combined Rating Scores

\begin{tabular}{|c|c|c|c|c|c|}
\hline YEAR & 2003 & 2004 & 2005 & 2006 & 2007 \\
\hline CAR & $9.870 \%$ & $9.609 \%$ & $9.123 \%$ & $8.735 \%$ & $7.268 \%$ \\
\hline RATING & 5 & 4 & 3 & 2 & 1 \\
\hline ASSET & 0.02567 & 0.03331 & 0.02800 & 0.03343 & 0.05412 \\
\hline RATING & 5 & 3 & 4 & 2 & 1 \\
\hline MANAGEMENT & 0.274773 & 0.300518 & 0.244571 & 0.204158 & 0.179635 \\
\hline RATING & 2 & 1 & 3 & 4 & 5 \\
\hline ROA & 0.005444 & 0.006633 & 0.007950 & 0.007958 & 0.006066 \\
\hline RATING & 1 & 3 & 4 & 5 & 2 \\
\hline ROE & 0.1289661 & 0.15878 & 0.194117 & 0.208796 & 0.186393953 \\
\hline RATING & 1 & 2 & 4 & 5 & 3 \\
\hline L1 & 0.382760 & 0.374212 & 0.481223 & 0.477248 & 0.501204 \\
\hline RATING & 4 & 5 & 2 & 1 & 3 \\
\hline L2 & 0.420107 & 0.420186 & 0.437401 & 0.457109 & 0.453074466 \\
\hline RATING & 1 & 2 & 3 & 5 & 4 \\
\hline RENITIVITY & 0.455738 & 0.488840 & 0.343223 & 0.447221 & 0.435899 \\
\hline
\end{tabular}

Table 8. Results of Combined Rating

\begin{tabular}{|c|c|}
\hline RATING 2003 & 47 \\
\hline RATING 2004 & 50.5 \\
\hline RATING 2005 & 63.5 \\
\hline RATING 2006 & 66 \\
\hline RATING 2007 & 43 \\
\hline
\end{tabular}

